\title{
PENGARUH SUHU VULKANISASI DAN KOMPOSISI BENTONITE CLAY YANG DIMODIFIKASI DENGAN ALKANOLAMIDA DARI BAHAN BAKU RBDPKO PADA PRODUK LATEKS KARET ALAM
}

\author{
Friska Erdiana Tambunan, Hamidah Harahap \\ Departemen Teknik Kimia, Fakultas Teknik, Universitas Sumatera Utara \\ Jl. Almamater Kampus USU Medan, 20155 Indonesia \\ Email: friskaerdiana@gmail.com
}

\begin{abstract}
Abstrak
Penelitian ini bertujuan untuk mengetahui pengaruh suhu vulkanisasi dan komposisi bentonite clay sebagai bahan pengisi yang baik terhadap sifat mekanik produk lateks karet alam. Dalam penelitian ini digunakan bentonite clay sebagai pengisi dan alkanolamida sebagai penyerasi. Bahan yang digunakan dalam penelitian ini adalah high ammonia lateks $60 \%$, bahan kuratif seperti sulfur, $\mathrm{ZnO}, \mathrm{ZDEC}$, antioksidan, $\mathrm{KOH}$, bentonite clay dan alkanolamida. Alkanolamida didapat melalui reaksi amidasi Refined Bleached Deodorized Palm Kernel Oil dengan dietanolamida. Penelitian dilakukan dengan melakukan pravulkanisasi lateks karet alam terlebih dahulu dengan formulasi tertentu, lalu divulkanisasi melalui teknik pencelupan. Variabel yang digunakan adalah jumlah pembebanan pengisi bentonite clay yaitu dari 5, 10, 15, 20, dan 25 gram serta waktu vulkanisasi selama 10 menit. Produk yang didapat diuji sifat mekaniknya, karakterisasi FTIR, karakterisasi SEM dan crosslink density. Hasil yang diperoleh berupa alkanolamida yang dihasilkan memiliki gugus yang diharapkan. Pembebanan pengisi bentonite clay termodifikasi alkanolamida mampu meningkatkan crosslink density dan sifat mekanik produk yang dihasilkan. Pembebanan optimum terjadi pada 10 gram dan suhu vulkanisasi optimum $120^{\circ} \mathrm{C}$.
\end{abstract}

Kata kunci : lateks karet alam, bentonite clay, alkanolamida, crosslink density, sifat mekanik, FTIR, SEM

\begin{abstract}
The is research aims to determine the effect of vulcanization temperature and composition of bentonite clay as good filler on mechanical properties of natural rubber latex product. In this study, we use bentonite clay as filler and alkanolamide as compatibilizer. The material used in this study are high ammonia latex 60\%, curative agents such as sulfur, $\mathrm{ZnO}, \mathrm{ZDEC}, \mathrm{AO}, \mathrm{KOH}$, bentonite clay and alkanolamide. Alkanolamide is synthesized from amidation reaction between Refined Bleached Deodorized Palm Kernel Oil and diethanolamine. The methodology includes pre-vulcanizing natural rubber latex with certain formulation, then vulcanized using dipping method. The variable used in this study is filler loading, from 5, 10, 15, 20, and 25 gram, and vulcanization time 10 minutes. The products were then tested in order to observe its mechanical properties, FTIR characterization, SEM characterization and crosslink density. The results show that the synthesized alkanolamide possess the functional group desired. Alkanolamide modified bentonite clay loading is capable of increasing crosslink density and mechanical properties of the products. Optimum filler loading is reported on 10 gram and optimum vulcanization at $120^{\circ} \mathrm{C}$.
\end{abstract}

Keywords : natural rubber latex, bentonite clay, alkanolamide, crosslink density, mechanical properties, FTIR, SEM

\section{Pendahuluan}

Karet alam merupakan suatu komoditi non migas, penghasil devisa Negara di Indonesia. Karet alam ini memiliki sifat fleksibilitas tinggi dan mampu berkristalisasi pada suhu rendah, apabila diregang. Produk-produk yang dihasilkan dari lateks karet alam antara lain seperti sarung tangan, benang karet, balon, kateter, pembalut luka elastis, kondom, tiup stetoskop dan lain-lain [13].

Pohon karet (Hevea brasiliensis) telah mencapai kepentingan komersial yang cukup besar. Pohon ini berasal dari daerah Amazon dan sekarang dibudidayakan di seluruh wilayah tropis Amerika Selatan, Afrika dan Asia [5]. Lateks karet alam umumnya mempunyai sifat mekanik yang lebih rendah dibandingkan dengan lateks karet alam yang sudah diberi tambahan bahan kuratif dan bahan pengisi [13]. Salah satu untuk meningkatkan sifat mekanik dari lateks karet alam perlu dilakukan kajian dengan menambahkan bahan pengisi (filler) ke dalam formulasi lateks karet alam, sehingga dapat memberikan nilai ketegangan tensile yang tinggi dan dapat digunakan untuk produksi bahan baku lateks [4]. Penambahan bahan pengisi di dalam lateks karet alam diyakini dapat menguatkan vulkanisat produk karet, sehingga kekuatan tarik dan sifat-sifat molekul lainnya seperti ketahanan sobek (tear strength), modulus elastisitas (modulus of elasticity), dan ketahanan lentur (flexural strength) menjadi meningkat [13].

Tulisan ini memaparkan hasil pembuatan produk lateks karet alam dan pengujian sifat mekanik dengan bahan baku lateks karet alam, dengan proses pra-vulkanisasi pada suhu $70^{\circ} \mathrm{C}$, serta proses vulkanisasi dengan suhu $100^{\circ} \mathrm{C}, 110^{\circ} \mathrm{C}$, dan suhu $120^{\circ} \mathrm{C}$. 


\section{Teori}

Lateks adalah cairan getah yang didapat dari bidang sadap pohon karet, pada umumnya berwarna putih seperti susu dan belum mengalami penggumpalan dengan atau tanpa penambahan bahan pemantap atau zat anti penggumpal. Lateks ini dapat diperoleh dengan cara menyadap antara kambium dan kulit pohon [3].

Karet alam (polyisoprene) termasuk kedalam elastomer yaitu bahan yang dapat direnggangkan dan dapat kembali seperti bahan semula. Karet alam memiliki beberapa keunggulan disbanding karet sintetik, terutama dalam hal elastisitas, daya redam getaran, sifat lekuk lentur (flex-cracking) dan umur kelelahan (fatigue) [12].

Proses pembuatan formulasi atau komponen karet alam, memiliki beberapa pilihan bahan kimia tambahan untuk meningkatkan kualitas vulkanisat produk karet alam. Bahan kimia tersebut memberikan sifat mekanik yang spesifik terhadap vulkanisat produk karet yang akan dibentuk [11].

Secara umum, pembuatan senyawa lateks karet alam dengan bahan kimia karet disebut senyawa (compound) lateks karet alam. Bahan kimia karet terdiri atas bahan kimia pokok dan bahan kimia tambahan. Bahan kimia poko yaitu bahan vulkanisasi, pencepat reaksi, pengaktif, penstabil, antioksidan, dan pengis. Sedangkan bahan kimia tambahan adalah bahan penyerasi antara pengisi dengan lateks karet alam.

Dalam penelitian ini bahan pengisi yang digunakan adalah bentonite clay. Bentonite Clay adalah suatu istilah nama dalam dunia perdagangan yang sejenis lempung plastis yang mempunyai kandungan mineral monmorilonit lebih dari $85 \%$ dengan rumus kimianya $\mathrm{Al}_{2} \mathrm{O}_{3} \cdot 4 \mathrm{SiO}_{2}$ x $\mathrm{H}_{2} \mathrm{O}$. Bentonite dapat dibagi menjadi 2 golongan berdasarkan kandungan alu-munium silikat hydrous, yaitu activated clay dan fuller's Earth. Activated clay adalah lempung yang kurang memiliki daya pemucat, tetapi daya pemucatnya dapat ditingkatkan melalui pengolahan tertentu. Sementara itu, fuller's earth digunakan di dalam fulling atau pembersih bahan wool dari lemak [2].

Bahan penyerasi yang digunakan dalam penelitian ini adalah alkanolamida yang disintesa dari bahan baku RBDPKO (Refined Bleached Deodorized Palm Kernel Oil). Alkanolamida adalah surfaktan bukan ionik dimana gugus hidroksil yang dimilikinya tidak cukup hidrofilik untuk membuat alkanolamida larut dalam air dengan sendirinya [8]. Oleh karena itu, diharapkan penggunaan alkanolamida dapat membuat interaksi antar fasa (interphase) antara bentonite clay dan lateks karet alam menjadi lebih kuat, dengan asumsi rantai hidrokarbon yang panjang akan berinteraksi dengan lateks karet alam yang bersifat non polar, sedangkan gugus amida akan berinteraksi dengan bentonite clay yang bersifat polar [3].

Pada penelitian Yuniati, Cebro, I.S (2013), melakukan analisa densitas sambung silang berpengisi karbon. Dari hasil penelitian diperoleh dengan densitas sambung silang menurun dengan meningkatnya bahan pengisi [13]. Hal ini menunjukkan bahwa film tersebut telah mengalami sambung silang yang baik semasa proses pemvulkanisasian dilakukan.

\section{Metodologi Penelitian}

Penelitian dilakukan di Laboratorium Lateks, Fakultas Teknik, Departement Teknik Kimia, Universitas Sumatera Utara. Bahan yang digunakan dalam proses pembuatan produk lateks karet alam yang terdiri dari lateks karet alam, bentonite clay, alkanolamida, dan bahan kuratif.

Tahapan-tahapan penelitian ini adalah pembuatan senyawa alkanolamida yang disintesa dari bahan baku RBDPKO (Refined Bleached Deodorized Palm Kernel Oil) dan pendispersian Bentonite Clay dan alkanolamida.

Pembuatan produk lateks karet alam dengan bahan baku lateks karet alam, pengisi bentonite clay berukuran 300 mesh, dan penyerasi alkanolamida. Komposisi pengisi yaitu 5, 10, 15, 20, dan 25; dengan konsentrasi pengisi $10 \%$ dan $15 \%$. Bahanbahan kuratif dan lateks karet alam amonia tinggi, seperti yang ditampilkan pada Tabel 1, di pravulkanisasi pada suhu $70^{\circ} \mathrm{C}$ selama 10 menit. Lateks karet alam pra-vulkanisasi dicampur dengan sistem dispersi pengisi dan diaduk. Persenyawaan lateks divulkanisasi pada suhu $100^{\circ} \mathrm{C}, 110^{\circ} \mathrm{C}$, dan $120^{\circ} \mathrm{C}$ selama 10 menit, dengan teknik pencelupan menggunakan pembentuk. Pembentuk yang digunakan berupa pelat tipis yang dicelupkan ke dalam persenyawaan karet

Pengujian produk lateks karet alam terdiri dari uji sifat mekanik, seperti kekuatan tarik (tensile strength) dan pemanjangan saat putus (elongation at break). Analisa terhadap densitas sambung silang (crosslink density), serta uji mekanik yang didukung oleh analisa Scanning Electron Microscopy (SEM).

Tabel 1. Bahan-bahan senyawa lateks pravulkanisasi

\begin{tabular}{|l|c|}
\hline \multicolumn{1}{|c|}{ Bahan } & Berat basah (gram) \\
\hline High Ammonia Lateks & 166,7 \\
$60 \%$ & 3 \\
Sulfur 50 \% & 3 \\
ZDEC 50\% & 0,83 \\
ZnO 30 \% & 2 \\
Antioksidan 50 \% & 3 \\
KOH 10 \% & $5,10,15,20,25$ \\
Pengisi 10\%, 15\% & \\
\hline
\end{tabular}




\section{Hasil dan Pembahasan}

\section{FTIR Alkanolamida}

Adapun hasil uji FTIR dari alkanolamida disajikan pada gambar berikut,

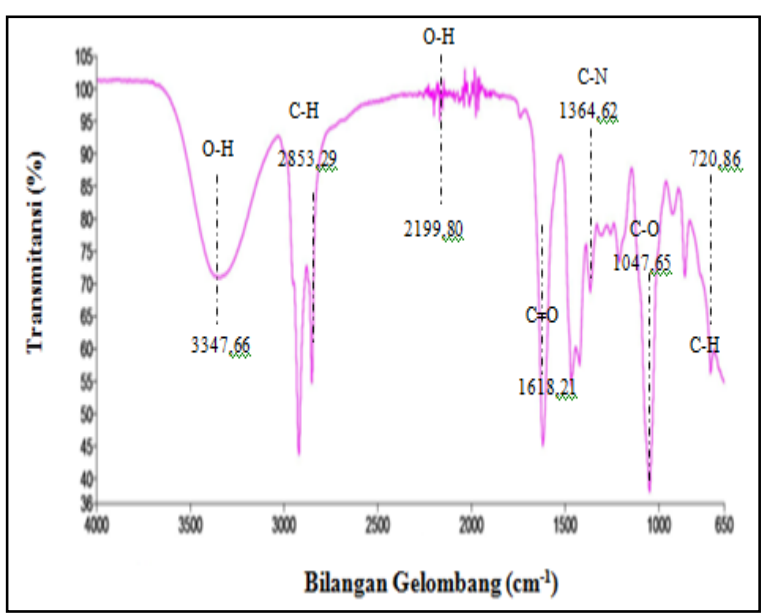

Gambar 1. FTIR alkanolamida

Gambar 1 menunjukkan hasil FTIR senyawa alkanolamida dapat dilihat munculnya puncak serapan pada bilangan gelombang $3347,66 \mathrm{~cm}^{-1}$ menunjukkan keberadaan gugus O-H. Munculnya puncak serapan pada bilangan gelombang 2853,29 $\mathrm{cm}^{-1}$ menunjukkan keberadaan gugus $\mathrm{C}-\mathrm{H}$ (metil). Munculnya puncak serapan pada bilangan gelombang 2199,80 $\mathrm{cm}^{-1}$ menunjukkan keberadaan gugus $\mathrm{O}-\mathrm{H}$ (asam karboksilat). Munculnya puncak serapan pada bilangan gelombang $1618,21 \mathrm{~cm}^{-1}$ menunjukkan keberadaan gugus $\mathrm{C}=\mathrm{O}$ (amida). Munculnya puncak serapan 1364,62 $\mathrm{cm}^{-1}$ menunjukkan keberadaan gugus $\mathrm{C}-\mathrm{N}$ (amina). Munculnya puncak serapan 1047,65 $\mathrm{cm}^{-1}$ menunjukkan keberadaan gugus $\mathrm{C}-\mathrm{O}$ (eter). Munculnya puncak serapan 720,86 $\mathrm{cm}^{-1}$ menunjukkan keberadaan gugus C-H (alkana) [1].

FTIR Produk Lateks Karet Alam Dengan Pengisi Bentonite Clay Dan Penyerasi Alkanolamida

Hasil analisa FTIR produk lateks karet alam menunjukkan bahwa terdapat gugus fungsi produk lateks karet alam dengan dan tanpa penambahan pengisi bentonite clay dan penyerasi alkanolamida dengan suhu vulkanisasi $100^{\circ} \mathrm{C}$. Terdapat puncak serapan pada bilangan gelombang $3938,64 \mathrm{~cm}^{-1}$ menunjukkan keberadaan gugus O-H (alkohol) pada produk lateks karet alam yang merupakan gugus fungsi utama bentonite clay. Hal ini menunjukkan bahwa pengisi bentonite clay telah terdispersi dalam film lateks karet alam. Selain itu munculnya puncak serapan 2727,35 $\mathrm{cm}^{-1}$ menunjukkan keberadaan gugus $\mathrm{C}-\mathrm{H}$ (metil), dan puncak serapan 2040,68 $\mathrm{cm}^{-1}$ menunjukkan keberadaan gugus $\mathrm{O}-\mathrm{H}$ (asam karboksilat). Munculnya puncak serapan 1130,29 $\mathrm{cm}^{-1}$ menunjukkan keberadaan gugus C-N (eter), dan munculnya puncak serapan $840,96 \mathrm{~cm}^{-1}$ menunjukkan keberadaan gugus C-H (alkena) [1].

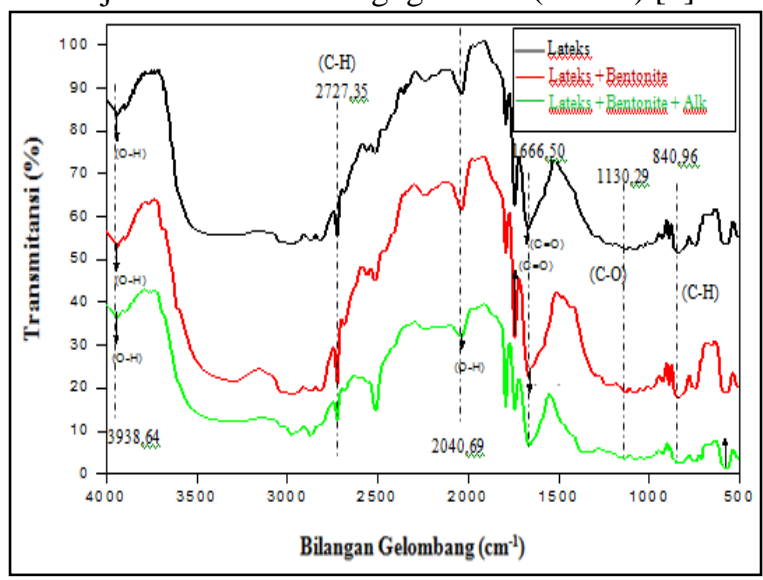

Gambar 2. FTIR Produk Lateks Karet Alam Dengan Pengisi Bentonite Clay Dan Penyerasi Alkanolamida

Terlihat pada Gambar 2, bilangan gelombang 2500 merupakan keberadaan gugus $\mathrm{OH}$, dimana gugus $\mathrm{OH}$ merupakan gugus fungsi dari lateks. Namun seiring dengan penambahan bentonite clay dan alkanolamida gugus $\mathrm{OH}$ tersebut menjadi bertambah. Begitu juga pada gelombang 2040,69 pada penambahan bentonite clay dan alkanolamida gugus $\mathrm{OH}$ tersebut menjadi berkurang bahkan mendekati titik habis.

Pengaruh Suhu Vulkanisasi Pada Produk Lateks Karet Alam Berpengisi Bentonite Clay Dan Penyerasi Alkanolamida Terhadap SifatSifat Mekanik Produk Lateks Karet Alam

\section{Densitas Sambung Silang (Crosslink Density)}

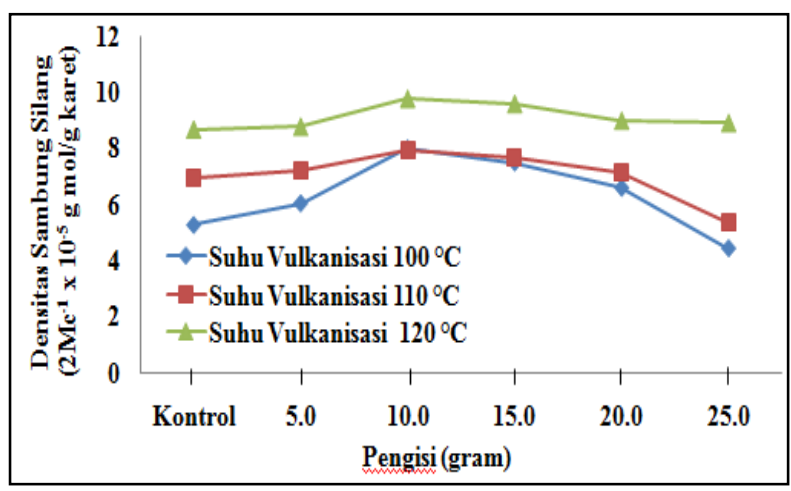

Gambar 3. Densitas Sambung Silang (Crosslink Density)

Gambar 3 menunjukkan bahwa nilai densitas sambung silang pada suhu vulkanisasi $120{ }^{\circ} \mathrm{C}$ lebih besar dibandingkan pada suhu vulkanisasi $100{ }^{\circ} \mathrm{C}$ dan $110^{\circ} \mathrm{C}$ untuk semua variasi 
penambahan pengisi. Ikatan sambung silang terjadi pada saat vulkanisasi karet berlangsung. Suhu vulkanisasi yang lebih tinggi menghasilkan ikatan sambung silang yang lebih banyak. Namun suhu vulkanisasi yang lebih tinggi juga dapat menghasilkan ikatan sambung silang yang tidak stabil atau dikenal sebagai proses reversi. Dimana, reversi akan menyebabkan nilai dari sifat-sifat mekanik menjadi menurun. Biasanya reversi terjadi pada keadaan vulkanisasi yang terlalu lama dan menggunakan suhu yang tinggi [9].

\section{Kekuatan Tarik (Tensile Strength)}

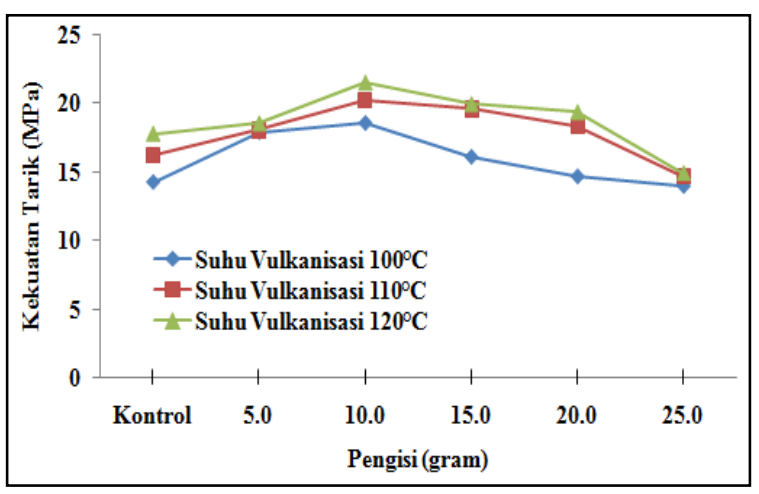

Gambar 4. Kekuatan Tarik (Tensile Strength)

Pada gambar 4, suhu vulkanisasi yang lebih tinggi menunjukkan kekuatan tarik yang lebih unggul. Namun, ketika pembebanan pengisi mencapai 20 dan 25 gram pengisi, menimbulkan turunnya kekuatan tarik. Pada pembebanan pengisi yang rendah, molekul karet lebih dominan sehingga peristiwa reversi dapat dihindari, namun pada pembebanan pengisi yang tinggi, molekul karet menjadi lebih terhalang satu sama lain, sehingga terjadi peristiwa reversi. Meningkatnya kekuatan tarik dari produk lateks karet alam dapat dilihat dengan meningkatnya crosslink density dari produk lateks karet alam. Sebelum melampaui titik kritis, kekuatan tarik akan berbanding lurus dengan densitas sambung silang. Dengan membandingkan Grafik 3 dan Grafik 4, dapat dilihat bahwa densitas sambung silang mencerminkan kekuatan tarik yang dihasilkan.

\section{Pemanjangan Saat Putus (Elongation at Break)}

Dari gambar 5 dapat dilihat bahwa pemanjangan pada saat putus cenderung menurun seiring dengan bertambahnya pembebanan pengisi mulai dari 10 gram dan menurunnya suhu vulkanisasi. Bertambahnya pengisi, maka sistem karet akan menjadi lebih padat, atau dengan kata lain histeresis meningkat. Histeresis merupakan perbandingan komponen viskos dan komponen elastis. Histeresis dapat digunakan untuk melihat seberapa besar energi yang tidak disimpan sebagai deformasi namun sebagai panas [7]. Dengan menambahkan pengisi komponen elastis sistem karet akan menurun sehingga menyebabkan sistem karet menjadi lebih kaku. Suhu vulkanisasi yang lebih rendah akan menyebabkan ikatan sambung silang yang lebih banyak. Sehingga lebih banyak ikatan yang menopang sistem karet sehingga menjadi lebih kaku.

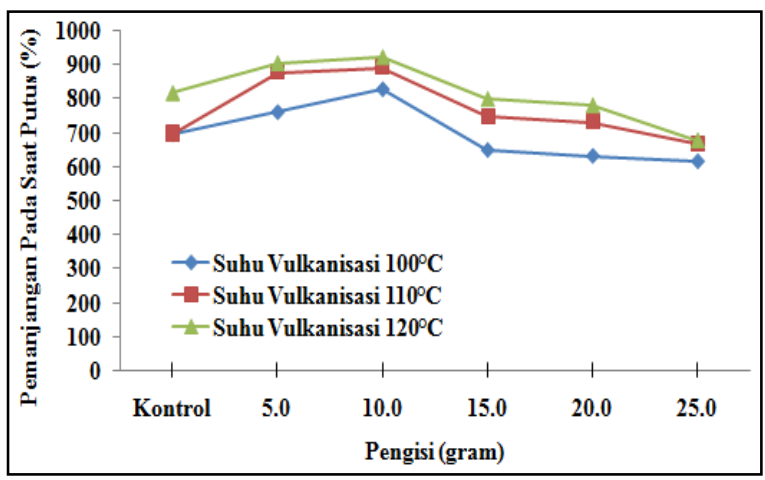

Gambar 5. Pemanjangan Saat Putus (Elongation at Break)

Pengaruh Konsentrasi Pengisi Bentonite Clay Dan Penyerasi Alkanolamida Terhadap SifatSifat Mekanik Produk Lateks Karet Alam

\section{Densitas Sambung Silang (Crosslink Density)}

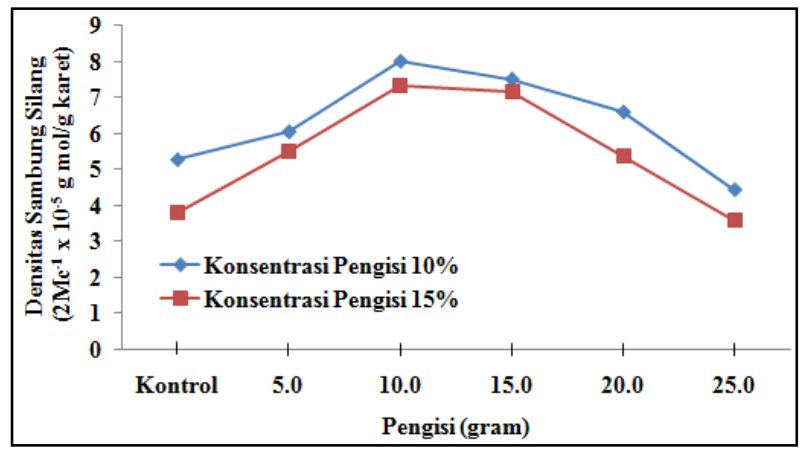

Gambar 6. Densitas Sambung Silang (Crosslink Density)

Gambar 6 menunjukkan dengan nilai densitas sambung silang (crosslink density) tertinggi terdapat pada konsentrasi pengisi $10 \%$ dibandingkan dengan konsentrasi pengisi $15 \%$. Pada Gambar 6 terlihat konsentrasi pengisi berpengaruh pada nilai densitas sambung silang suatu produk lateks karet alam. Dimana konsentrasi pengisi lebih tinggi akan menghasilkan ikatan sambung silang yang lebih sedikit dibandingkan pada konsentrasi pengisi yang lebih tinggi. Pada konsentrasi yang lebih rendah juga dapat menghasilkan ikatan sambung silang yang tidak stabil atau dikenal dengan proses reversi. Dimana, reversi akan menyebabkan nilai dari sifat mekanik menjadi menurun [9]. 


\section{Kekuatan Tarik (Tensile Streng)}

Gambar 7 menunjukkan dengan nilai kekuatan tarik (tensile strength) tertinggi terdapat pada konsentrasi pengisi $15 \%$ dibandingkan pada konsentrasi pengisi $10 \%$. Konsentrasi pengisi mempengaruhi sifat kekuatan tarik dari produk lateks karet alam. Konsentrasi pengisi yang lebih tinggi dapat membantu kekuatan tarik sehingga produk menjadi lebih kaku.

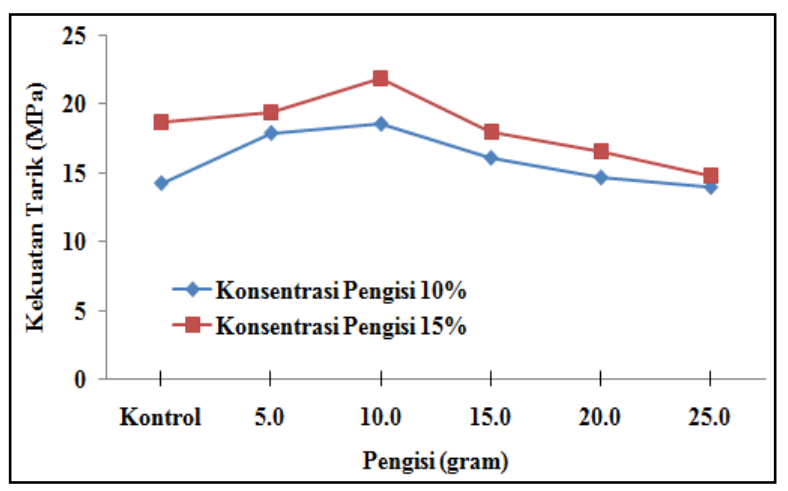

Gambar 7. Kekuatan Tarik (Tensile Strength)

Pada saat penambahan bahan pengisi kekuatan tarik akan semakin meningkat hingga penambahan bahan pengisi 10 gram. Kemudian terjadinya penurunan pada saat penambahan bahan pengisi dari 15 gram hingga 25 gram. Penurunan nilai kekuatan tarik ini disebabkan karena bentonite clay mengandung layered silika lebih sedikit, hal ini dapat membuat daerah antarfasa menjadi lemah sehingga kekuatan yang dimiliki bahan produk lateks karet alam semakin menurun. Pada konsentrasi pengisi lebih rendah mengakibatkan kekuatan tarik menurun. Hal ini disebabkan karena komposisi bentonite clay dan alkanolamida jauh lebih tidak sebanding dengan produk lateks karet alam.

\section{Pemanjangan Saat Putus (Elongation at Break)}

Gambar 8 menunjukkan bahwa hasil pemanjangan pada saat putus (elongation at break) tertinggi di peroleh pada konsentrasi pengisi $15 \%$. Sehingga dapat dilihat semakin tinggi konsentrasi suatu pengisi maka hasil pemanjangan pada saat putus suatu produk lateks alam akan semakin meningkat, mengakibatkan produk vulkanisat yang dihasilkan cenderung akan bersifat lebih kuat dibandingkan konsentrasi pengisi $10 \%$. Hal ini disebabkan pada konsentrasi pengisi lebih tinggi bentonite clay yang terkadung lebih banyak dibandingkan konsentrasi pengisi $10 \%$.

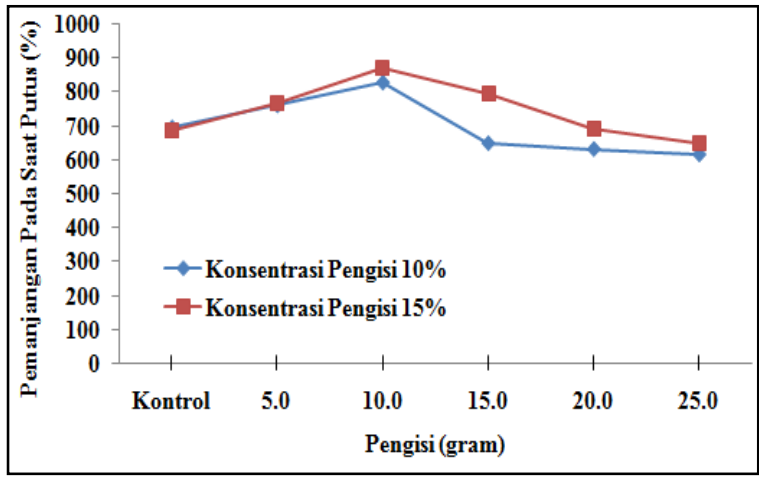

Gambar 8. Pemanjangan Saat Putus (Elongation at Break)

Penambahan bahan pengisi 15 gram hingga 25 gram pemanjangan saat putus akan menurun, karena disebabkan filler mengalami penggumpalan. Gumpalan (aglomerasi) akan memperkecil luas permukaan dan seterusnya akan melemahkan interaksi di antara pengisi dan matriks sehingga mengakibatkan penurunan sifat fisik bahan polimer. Terjadinya kenaikan dan penurunan pemanjangan pada saat putus ini terjadi dikarenakan adanya peningkatan pengisi yang mengakibatkan kemampuan deformasi penurunan pada antarmuka pengisi dan matriks sampel [6].

\section{Karakteristik Scanning Electron Microscope SEM}

Tanpa Pengisi Bentonite Clay Dan Tanpa Alkanolamida Dengan Perbesaran 3000x

Pada gambar 9 menunjukkan produk lateks karet alam tanpa pengisi bentonite clay dan tanpa alkanolamida dengan perbesaran 3000x terlihat bahwa lateks karet alam mengandung partikelpartikel karet alam yang membuat sifat lateks karet alam menjadi elastis dan kuat.

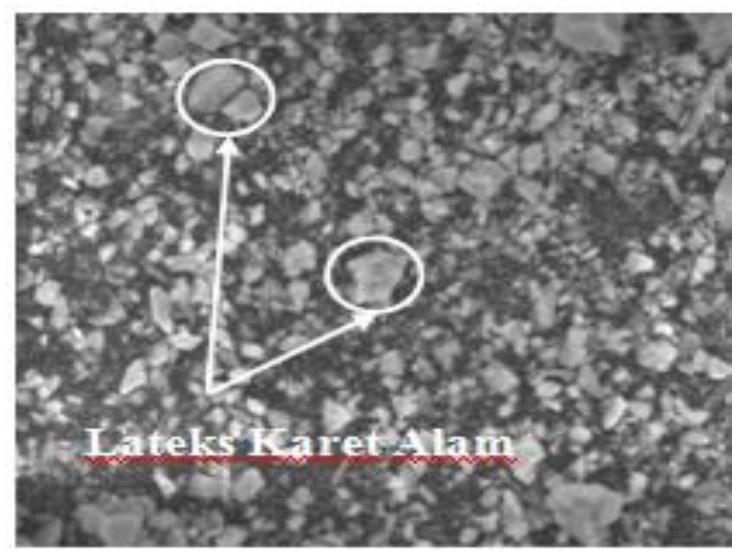

Gambar 9. Tanpa Pengisi Bentonite Clay Dan Tanpa Alkanolamida Dengan Perbesaran 3000x 


\section{Dengan Pengisi Bentonite Clay Dan Tanpa Alkanolamida Dengan Perbesaran 3000x}

Pada gambar 10 menunjukkan produk lateks karet alam dengan pengisi bentonite clay dan tanpa alkanolamida dengan perbesaran 3000x terlihat bahwa telah terdapat partikel pengisi bentonite clay dalam lateks karet alam. Namun pengisi bentonite clay tidak terdispersi dengan baik dan cenderung mengalami aglomerasi. Hal ini disebabkan karena perbedaan sifat kepolaran antara pengisi bentonite clay dan matriks lateks karet alam, dan memperlihatkan peningkatan agregat yang lebih banyak dibandingkan dengan tanpa pengisi bentonite clay dan tanpa alkanolamida.

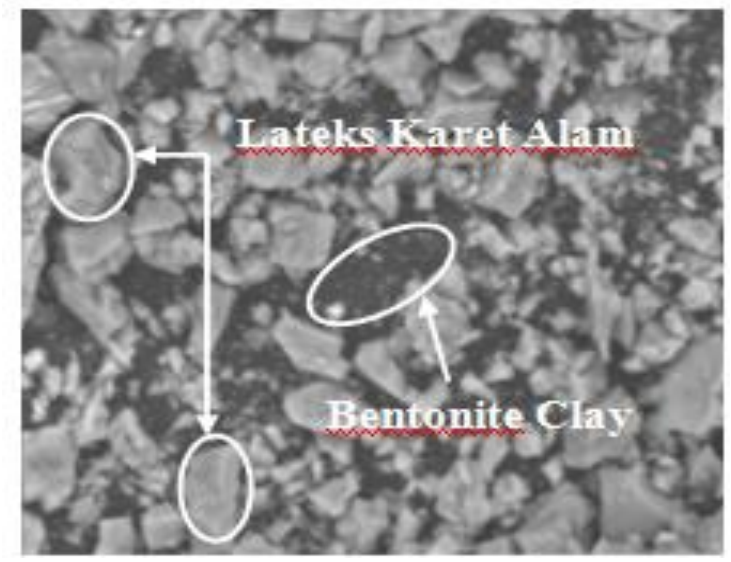

Gambar 10. Dengan Pengisi Bentonite Clay Dan Tanpa Alkanolamida Dengan Perbesaran 3000x

\section{Dengan Konsentrasi Pengisi $10 \%$ Dengan Perbesaran 3000x}

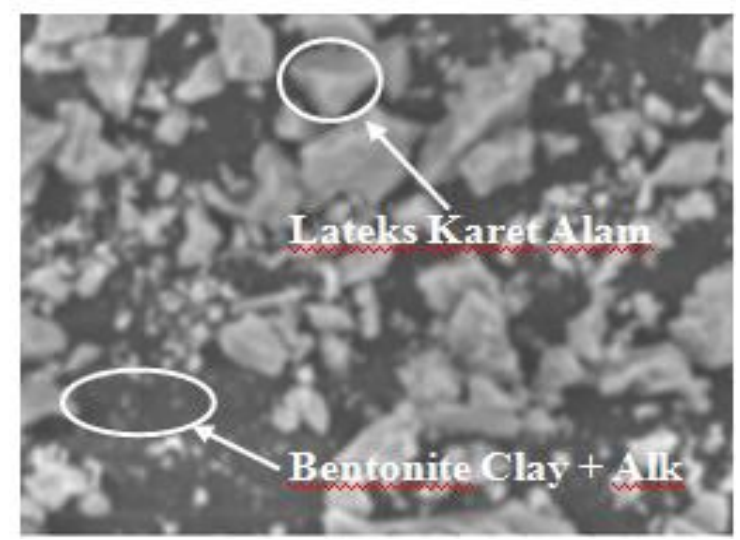

Gambar 11. Dengan Konsentrasi Pengisi 10\% Dengan Perbesaran 3000x

Gambar 11 menunjukkan analisa SEM pada produk lateks karet alam dengan konsentrasi pengisi $10 \%$ dengan perbesaran 3000x terlihat bahwa pengisi dan bahan kuratif terdispersi secara homogen dengan lateks karet alam.

\section{Dengan Konsentrasi Pengisi 15\% Dengan Perbesaran 3000x}

Gambar 12 menunjukkan analisa SEM pada produk lateks karet alam dengan konsentrasi pengisi $15 \%$ dengan perbesaran 3000x menunjukkan bahwa terjadi aglomerasi (penggumpalan) yang meningkat pada produk lateks karet alam dan memperlihatkan permukaan yang halus dan agregat yang terbentuk sedikit lebih kecil dibandingkan konsentrasi $10 \%$ pengisi.

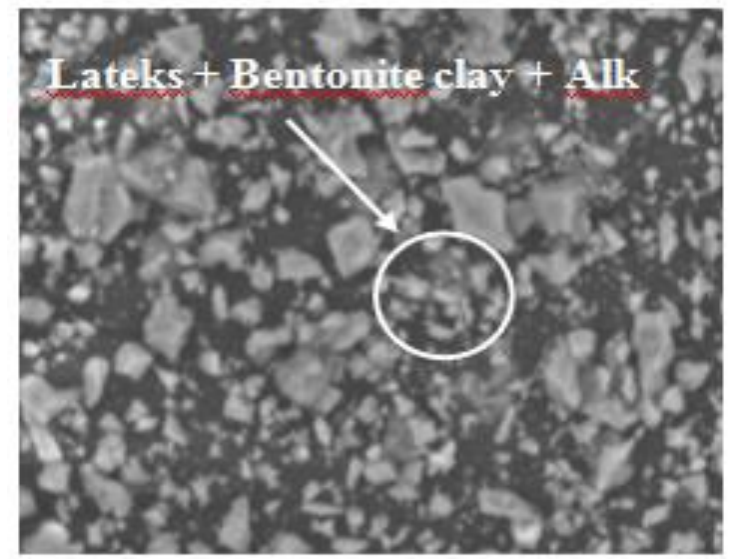

Gambar 12. Dengan Konsentrasi Pengisi 15\% Dengan Perbesaran 3000x

\section{Kesimpulan}

Adapun kesimpulan yang dapat diambil dari penelitian ini adalah:

1. Dari hasil analisa spektrum Fourier Transform Infra Red (FTIR), bentonite clay sebagai bahan pengisi memiliki gugus polar yang mampu memodifikasi penyerasi alkanolamida dan gugus non polar yang mampu memodifikasi matriks lateks karet alam.

2. Suhu vulkanisasi yang lebih tinggi akan meningkatkan terjadinya reaksi sambung silang karena partikel-partikel seperti bahan kuratif dan pengisi akan lebih mudah berdifusi dalam produk lateks karet alam. Dan suhu vulkanisasi yang lebih tinggi dapat juga menimbulkan proses reverse.

3. Bentonite Clay termodifikasi alkanolamida mampu meningkatkan crosslink density dan kekuatan tarik dari produk lateks karet alam dengan pembebanan optimum sebesar 10 gram

4. Meningkatnya bentonite clay memberikan efek negatif pada sifat mekanik film produk lateks karet alam. Hal ini disebabkan oleh adanya penggumpalan atau aglomerasi dari bentonite clay sehingga menyebabkan gangguan pergerakan molekul karet. 


\section{Daftar Pustaka}

[1] Akiba, M.Z, and Hasyim, A, Vulcanization and Crosslinking in Elastomer, Progress In Polymer Science, Minden, Penang Malaysia, 1997.

[2] Allcock, H.R, Contemporary Polymer Chemistry, Pearson Education International, New Jersey, 2003.

[3] Anasri, Pembuatan Alkanolamida Dari Hasil Amidasi RBDPKO, RBD Olein, RBD Stearin Dengan Dietanolamin, Tugas Akhir, Program Studi Kimia Ekstensi USU, Medan, 2010.

[4] Eqwaikhide, P.A, Akporhonor, E.E, Okieimen, F.E, The Characterization of Carbonised Coconut Fibre as Fillers in Natural rubber Formulation, Trends Applied Science Research, 2008.

[5] John, Sajeev, Mechanical Properties of Natural Rubber Latex Coagulated by a Novel Coagulant-Yeast, international Journal of Advanced Engineering Sciences And Technologies 8 : 177-178, 2011.

[6] Khalil, H.P.S, Bhat, I.B, Sartika, M.Y, Degradation, Mechano-Physical, And Morphological Properties of Empty Fruit Bunch Reinforced Polyester Composites, BioResources 5(4) 2278-2296, 2010

[7] Leroy, Eric, Anouar Souid. Remi Deterre, A Continuous Kinetic Model of Rubber Vulcanization Predicting Induction and Reversion, Polymer Testing vol. 32, 575-582, 2013.

[8] Merry Ginting, Sintesis Alkanolamida Dari Minyak Jarak (Ricinus communis Linn) Sebagai Sumber Poliol Dan Pemanfaatannya Untuk Pembuatan Poliuretan, Tugas Akhir, Program Sarjana USU, Medan, 2011.

[9] Milani, G, Leroy, Milani, Deterre, Mechanistic Modeling of Reversion Phenomenon in Sulphur Cured Natural Rubber Vulcanization Kinetics, Polymer Testing (32), 1052-1063, 2013.

[10] Mili Purbaya, Tutu I.S, Chessa A.S, Mutia T.F, Pengaruh Beberapa Jenis Bahan Penggumpal Lateks Dan Hubungannya Dengan Susut Bobot, Kadar Karet Kering Dan Plastisitas, Prosiding Seminar Nasional AVoER ke-3 Universitas Sriwijaya, Palembang, 2011.

[11] Sasongko, A.R, Studi Pengaruh Ukuran Partikel dan Jumlah PHR carbon black Sebagai Bahan Pengisi Terhadap Sifat Mekanik Produk Karet Alam, tugas Akhir, Fakultas Matematika Dan Ilmu Pengetahuan Alam, Universitas Indonesia, Depok, 2012.

[12] Wiwien, A, Darsono, Faisal, W, Kajian Metode Vulkanisasi Lateks Karet Alam Bebas
Nitrosamin dan protein Alergen, Pusat Teknologi Akselerator dan Proses Bahan BATAN, Yogyakarta, 2010.

[13] Yuniati, Irwin, S.C, Efektifitas Bahan Pengisi Karbon Pada Lateks Terhadap Sifat Fisik Swelling Indeks, Proceeding Seminar Nasional Tahunan Teknik Mesin XII (SNTTM XII) Universitas Lampung, Bandar Lampung, 2013. 